\title{
FIGURATIVE LANGUAGE USED IN SAUDI NEWS HEADLINES RELATED TO CORONAVIRUS (COVID-19)
}

\author{
Fadi Maher Al-Khasawneh \\ King Khalid University, Abha, Saudi Arabia \\ E-mail: falkhasoneh@kku.edu.sa
}

Received: 2021-08-19

Accepted: 2021-10-29

\begin{abstract}
Abstarct
Figurative language is a part of Stylistics and there was much research on how figurative language was used in different contexts. The present research aimed at analyzing the figurative language used in Saudi news headlines related to Coronavirus (COVID-19). A descriptive qualitative research design was used in this study. The data source of this study was the Saudi Press Agency (SPA), and the data were headlines related to Coronavirus (COVID-19) published from the period from February 15 to March 31, 2020. The obtained data from this study were organized, classified, and coded. The findings of this study revealed that there were seven speech figures used in this study (personification, hyperbole, understatement, paradox, synecdoche, apostrophe, and metonymy). The most used speech figure was personification and the least used one was metonymy. Each type of these speech figures had its own function such as to expand meaning, create intense emotions, and express a lot in a limited space. The researcher provides some recommendations for future research work in order to get more insights and contributions to this topic.
\end{abstract}

Keywords: figurative language, coronavirus, news headlines, Saudi Press Agency

\section{Introduction}

A language is a group of symbols that are used by people to communicate with one another. These symbols could take a written or a spoken form. Language plays a significant role in communication, interaction, and obtains messages and information from other people. Language is also important for people to establish and maintain relationships with each other. According to Kuolie (2010), language is existent for exchanging ideas and information between people. Figurative language is one type of language style that focuses on connotative meaning rather than denotative meaning. In other words, figurative language uses words and expressions that go beyond the literal meaning of sentences (Nurfiyanti, 2016). Figurative language is a persuasive language style that tends to add further dimensions to language style. This type of language would draw the attention of readers and make the reading process to be more exciting (Perrine, 1969). Users of figurative language convey messages and ideas in an unusual way and it is used in both linguistics and literature (Widyanti, 2013). When words or expressions cannot be understood literally or cannot be literally actual, people will definitely understand figuratively (Furniss, 1996).

News agencies offer a wide range of linguistic varieties that are distinctive in order to draw readers' attention. To achieve that particular purpose, reporters employ various 
Figurative Language Used in Saudi News Headlines Related to Coronavirus (Covid-19), Fadi Maher AlKhasawneh

techniques in writing news headlines. These headlines are written in a featured sense that is totally different from the unusually used language (Moe, 2014). For achieving that special style of written headlines, special grammar rules are applied in which the interests and attitudes of readers are appealed. The purpose of paying more attention to news headlines is because headlines are the whole news report refinement. Readers of news decide on reading the whole news report based on the headline it contains. Consequently, news reporters would employ attractive news headlines in order to spread the reading of news (Chen, 2018).

At the end of 2019, the world experienced the emergence of a novel virus called Coronavirus (Covid-19). This virus has first appeared in one of the most significant business hubs in China (Wuhan). This virus killed more than 1.800 and more than 70.000 people have been infected from this virus (Shereen, Khan, Kazmi, Bashir, \& Siddique, 2020). Since then, the virus kept its spread all over the world and it killed 46.063 individuals and infected 872.066 people (www.worldmeters.com, April $1^{\text {st }}, 2020$ ). Until these days, the international news agencies are still full of daily news headlines concern with the latest developments of Coronavirus (Covid-19). Therefore, the researcher found it very much interesting to explore the types and functions of figurative language used in the Saudi Press Agency (SPA), that are related to Coronavirus news headlines. The results of this study could be beneficial to readers in different ways. First, the present study will add to the body of literature concerning the use of figurative language, especially the figurative language used in news headlines pertaining to pandemic cases. It will also benefit the academicians on how figurative language is used in these particular circumstances we all experience these days. In addition, academicians would be aware of the creative approaches of writing news headlines, which could be implemented in teaching stylistics for English major students. The results of the present study can be used as a source of future studies conducted in the Stylistics domain since it focuses on the use of figurative language in news headlines related to a novel case (Coronavirus).

The findings obtained from this study could contribute to the academic field both theoretically and practically. In addition, the findings of this study could enrich the body of literature deal with this topic. It can provide additional information for researchers who are interested in this topic. In addition, researchers interested in stylistics and/or pragmatics could use this study as a reference for their future research. Practically, the findings of this study give more insights about the different types of speech figures used in general, and in news headlines in particular. Readers will get more awareness with regard to the different functions of using speech figures in different contexts. Furthermore, this study is one of the rare studies that deal with using figurative language in non-literary contexts. It focuses on a novel pandemic (COVID-19) which has recently spread all over the world. Hence, readers will have the opportunity to see how online news agencies dealt with this virus. News editor would be in a good position to figure out the figurative language used in news headlines related to this pandemic. According to this, they might attempt to be more creative and flexible in using such types of figures.

\section{Literature Review}

\subsection{Stylistics}

Verdonk (2002) defined stylistics as linguistic distinguished expressions and descriptions of their function and impact. Simpson (2004) views stylistics as an approach of textual interpretation in which the priority is given to language. Stylistics is more common in literary 
texts, but it could also be used in other areas of language studies such as applied linguistics. Stylistics shows writers' proficiency in all aspects of language use such as journalism, advertising, casual conversation, and music. These forms of discourse give writers the opportunity to show their proficiency in language use (Simpson, 2004). In stylistics analysis, much attention is given to objectivity instead of subjectivity. The objective of stylistics is not influenced by the point of view or personality of the evaluator (Kuolie, 2010). Moreover, stylistics is meant to identify the linguistic features of certain works, and these features could be sounds, speech patterns, sentence structure, lexical analysis, frequency of language parts of speech, or the types of speech figures (Kuolie, 2010). The main objective of stylistics analysis is to examine how language resources are employed to produce genuine messages (Widdowson, 2003). The produced messages consider social traditions and conventions in order to understand the actual meaning of that message (Widyanti, 2013). The field of stylistics also focuses on the types of messages and linguistic units of communication, and how conventions are revealed in various types of texts (Widdowson, 2003).

\subsection{Types of Figurative Language}

As mentioned earlier, figurative language is used to indicate non-literal meaning. According to Leech and Short (2007), figurative language contains tropes and schemes. Tropes are defined as the deviation or anomaly of the content, while schemes are defined as prominent recurrence of certain expressions. Schemes include some categories such as schemes of grammar, schemes of phonology, and schemes of a lexeme. Each one of these schemes has its own patterns. Furthermore, tropes contain certain figures of speech and their particular functions. Perrine (1969) classifies figurative language into three different classes: figures of comparison, figures of association, and figures of contrast. An introduction of each type of these figures will be explained in the following section.

\subsubsection{Figures of Comparison}

Perrine (1969) classifies the figurative language of comparison into four categories: metaphor, simile, personification, and apostrophe. A metaphor is defined as the implied comparison between two things which are not alike (Simpson, 2004). In this figure of speech, the writer or speakers compare something with something else to assist in understanding the idea that he/she tries to convey. For example, the following metaphor the test was a breeze implies that the test was very easy, and the metaphor my father is boiling mad implies that my father is so angry now. A simile is defined as the explicit comparison between two different things. This is to create an interesting connection between both objects (Kennedy \& Gioia, 2007). For instance, thin people might be compared to a rake as thin as a rake or comparing clear explanation to mud as clear as mud. The difference between metaphor and simile is that simile uses comparative words such as like and as.......as. The third type of comparison figure of speech is personification. This category is defined as assigning a people's quality to an inanimate object. This figure is widely used in literature in general and in poetry in particular. For example, the opportunity is knocking my door; in this statement, the power of knocking is given to the opportunity which, of course, is non-human and thus cannot knock. The personification in this statement implies that there a good luck approaching me and I should exploit it. The last type of this category is apostrophe which is viewed as addressing a dead, absent, or even non-human object. This type of language figure often ends with an exclamation mark (Kennedy \& Gioia, 2007). This type of figurative language is also used in literature. One example of this figure is Oh death, 
Figurative Language Used in Saudi News Headlines Related to Coronavirus (Covid-19), Fadi Maher AlKhasawneh

who are you going to take from me next? Apostrophe and personification have many similarities; the only difference is that apostrophe does not give a people's quality or characteristic to the object of the sentence.

\subsubsection{Figures of Association}

In respect of the figurative language of association, Perrine (1969) classifies this category into four types: metonymy, symbol, synecdoche, and allegory. Metonymy is defined as a speech figure where the name of a thing is replaced with another name which is closely related to the meant object. One of the most famous metonymies that are widely used in our daily life is the pen is mightier than the sword. In this metonymy, the pen refers to written words and the sword refers to military troops. The second type of this category is 'symbol' which is defined as an object which represents another. This type of figurative language is used to provide a more significant and deeper meaning (Kennedy \& Gioia, 2007). For instance, the dove is a symbol of peace, red color is a symbol of love and romance, and black color is a symbol of death and sadness. Synecdoche is defined as a figure of speech in which a part of something is used to represent a whole. For example, the word glasses refer to spectacles and sails refers to the whole ship. The last type of this category is an allegory which is defined as a type of figurative language which encompasses a picture or story with a hidden meaning (Kennedy \& Gioia, 2007). This type of speech figure is widely used in literature which tends to show some symbolic ideas. The story of George Orwell 'Animal Farm' is one good example of allegory. In this story, the author shows communist people as animals during the Russian revolution led by Leon Trotsky.

\subsubsection{Figures of Contrast}

Figurative language of contrast involves four types which are paradox, hyperbole, understatement, and irony. According to Kennedy \& Gioia (2007), a paradox is viewed as a statement that seems contradictory, but in fact, it conveys deep meaning. For example, the paradox your enemy's friend is your enemy and truth is honey, which is bitter are two apparent statements that seem contradictory but they reflect deep meanings. Hyperbole involves using exaggerated statements that are not meant to be taken literally. Examples of this type of speech figures are I got a headache, I feel my head as big as this room and I am starving, I could eat a cow. Understatement is defined as viewing an object as smaller, worse, or even less significant than it really is Kennedy \& Gioia (2007). For instance, there is a rainy storm, we cannot go out, but at least trees will get watered. In this understatement, people might try to reduce the fear of the damage that the rainy storm might cause. The last type of this category is irony which is defined as using different words to represent the actual meaning the speakers want to say. For example, my friend is as intelligent as donkeys; in this statement, the speaker is making fun of his friend's mental ability. All of the aforementioned types of figurative language seek to achieve some functions such as raising readers' imagination, expanding meaning, creating intense emotions, and expressing a lot in a limited space. Each one of these functions plays an important role in decorating the message that the headline intends to convey (Perrine, 1969).

\subsection{News Headlines}

News headlines are always seen in many online and written news agencies. A headline is a communication means used at the top of editor letters, news articles, and advertisements. These headlines are often written in bold big letters to show the main topic of the content it 
contains (Saxena, 2006). A headline often contains a statement or a few statements to show the main points of the article news (Al-Qudsy, 2016). The demonstration style of news headlines aims at drawing the attention of readers; this could also be ensured through employing some motivating words for reading. The selection of headline words should go through a strict process in order to create the wanted headline (Saxena, 2006).

\subsection{Saudi Press Agency}

The establishment of the Saudi Press Agency (SPA) was in (1971) and it was the first news agency in Saudi Arabia. The agency aims at disseminating and collecting news locally and internationally. The agency is considered important to convoy with the progress, advancement, and development in Saudi Arabia. It also reflects and transfers various kinds of news and information to local and international people. Since its foundation, the agency proceeds with big paces to achieve its main goal to be an effective and modern news agency. The agency became the first choice of Saudi people to get news and they consider it as the main source of reliable and credible news. The trustworthiness that the agency gained was because of its authentic and objective style of work and professional outlook. The modern means of communication in Saudi Arabia enables the agency to rapidly distribute and spread of its news services. Hence, the services of this agency become accessible to the various types of government departments, media, and agencies. Since its foundation, the SPA tends to improve mutual relationships with the Arab world and international developing countries. It also aims at building close ties with other media bodies around the world to exchange news and information. SPA is co-founder of the Arab News Agencies (ANA), the Agency of Gulf News (AGN), and the International Islamic News Agency (IINA). The agency holds periodic meetings and conferences to revise the items of joint cooperation between regional and international news agencies. It is also an active participant in the international conferences held by various news agencies (www.spa.gov.sa). The following is an example of the interface of the Saudi Press Agency website.

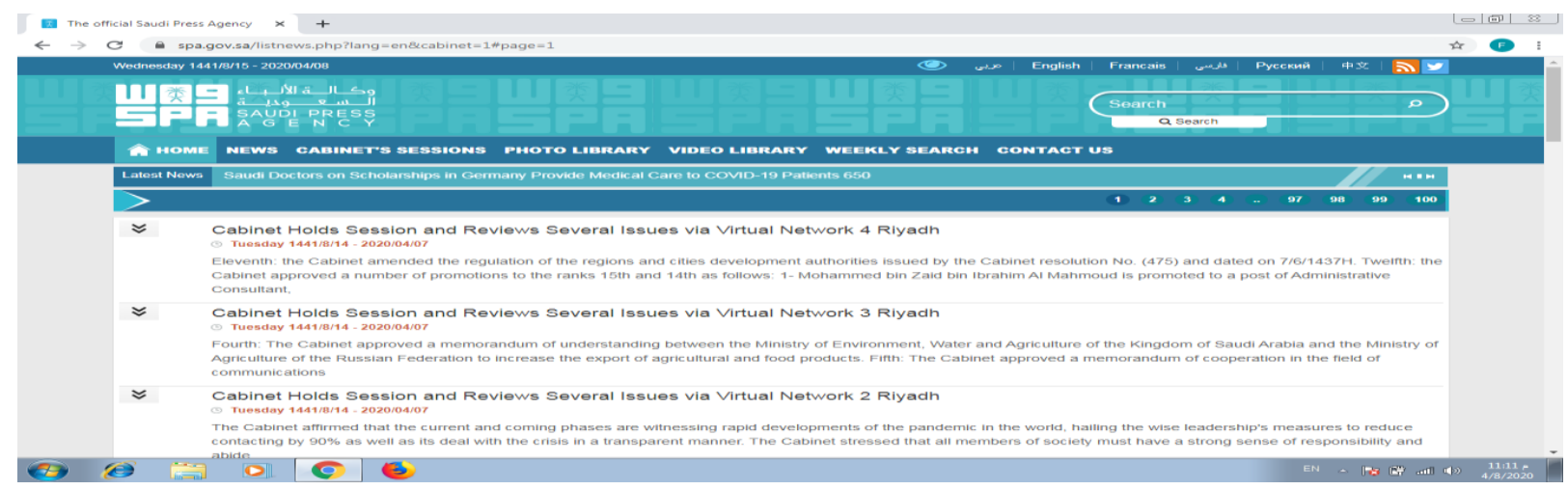

Figure 1: The Interface of Saudi Press Agency Website

\subsection{Previous Studies}

Much research (Al-Qudsy, 2016; Chen, 2018; Chuang, 2012; Lamichhane, 2017; MolekKozalowska, 2014). Al-Qudsy (2016) studied the speech figures employed in Jakarta Post Newspaper headlines under two local issues in Indonesia. The results of this study showed that there are six types of figurative language used in the headlines of those two issues. These types include simile, synecdoche, metaphor, hyperbole, irony, and apostrophe. Each one of the used speech figures has its own function in the headlines. Chen (2018) analyzed the use of metaphors in news headlines of The New York Times newspaper. The researcher 
Figurative Language Used in Saudi News Headlines Related to Coronavirus (Covid-19), Fadi Maher AlKhasawneh

followed Lakoff \& Johnson's classification of metaphors to analyze the expressions of metaphors in those English news headlines. The classification of metaphors as stated by Lakoff \& Johnson (1980) includes orientation metaphors, structural metaphors, and ontological metaphors. The findings of this study showed that English news headlines of The New York Times newspaper contained the three types of metaphors and the researcher provided one example for each type.

Chuang (2012) studied the use of metaphors and metonymy in the headlines of different genres in the Apple Daily newspaper. The findings revealed that both metaphors and metonymies were used more frequently in sports and entertainment headlines; the fighting idea was the base of using metaphors in those headlines. Lammichhane (2017) investigated the rhetorical features of English news headlines in two Nepalese newspapers. The researcher selected some news headlines from two newspapers (i.e. The Himalayan Times and The Kathmandu Post). The results of this study showed that the most rhetorical features used in both newspapers were alliteration and metaphor. In a similar vein, MolekKozalowska (2014) analyzed the coercive metaphor application in news headlines from a corpus of 400 most-read headlines of the British news agency The Daily Mail. The findings of this study revealed that the coercive metaphor applications used in those headlines were imaging, animalization, simplification, dramatization and confrontation.

The previous review of the literature illustrated that each of the above studies has studied figurative language from different angles. Al-Qudsy (2016) studied the figurative language used in news headline of two local issues. Chen (2018) investigated the use of one figurative feature in news headlines which is a metaphor, while Chuang (2012) studied the use of only two figurative features of news headlines that are metaphors and metonymy. Lammichhane (2017) explored the use of the figurative language of randomly chosen headlines of two Nepalese newspapers, while Molek-Kozalowska (2014) studied the use of a specific type of metaphor (i.e. coercive metaphor) in headlines of one of the British newspapers.

It is apparent from the previously mentioned studies that additional research is necessary to explore the figurative language used in English headlines in general and the figurative language used in the English headlines related to Coronavirus (COVID-19) in particular. The researcher strongly believes the need for this study as no studies have been conducted to investigate this issue due to the recent outbreak (COVID-19). Therefore, the present study aims to bridge the gap by giving answers to the research question: - What types of figurative language used in Saudi news headlines related to Coronavirus?

\section{Methodology}

The present study employs the descriptive qualitative design since it focuses on a certain linguistic phenomenon and its contextual interpretation. This design provides an indepth understanding of the figurative language used in the news headlines of the recent pandemic disease (COVID-19). This could contribute to understanding how press agencies have dealt with this disease and how they described it.

\subsection{Data Source}

The researcher focused on the written headlines about Coronavirus (COVID-19) selected from the online website of the Saudi Press Agency (SPA) during the period from February 15, 
2020, to March 31, 2020. This period was the beginning of disease propagation around the world. The researcher chose the Saudi Press Agency (SPA) as it is the first official news agency in Saudi Arabia providing news in the English language.

\subsection{Data collection}

The present study used document analysis as a method of data collection. The researcher collected the data from the website of the SPA with a sole focus on the news headlines related to Coronavirus (COVID-19). The process of data collection involves a comprehensive selection of news headlines to find suitable data that serve the objectives of this study. The next step was to analyzing the selected headlines to understand the context of the used speech figures. Then, the researcher checked the conformity of selected headlines with the types of figurative language mentioned in the literature review. Finally, the researcher categorized the selected headlines into their figurative classes in preparation to analyze it.

\subsection{Data Analysis}

In this qualitative research, the researcher used the inductive frequency method of analysis which involves going from specific to general analysis. The researcher observed and interpreted the types of figurative language used in English headlines. The researcher has followed certain steps in order to analyze the data collected from the present study. First, the data has been collected and organized before moving to the next step. Second, the headlines have been classified according to their type of figurative language. Third, the types of speech figures have been coded based on the type of speech figures it belongs to. Fourth, the speech figures have been interpreted and the function of each figure has also been explained.

\section{Findings and Discussion}

As mentioned earlier, this study aimed at exploring the figurative language used by the Saudi Press Agency (SPA) pertaining to Coronavirus (COVID-19). This section provides the findings obtained from this study (see Table 1).

\begin{tabular}{cccc}
\hline Number & Speech Figure & Occurrences & Percentage \\
\hline 1. & Personification & 37 & $36.7 \%$ \\
\hline 2. & Hyperbole & 27 & $26.8 \%$ \\
\hline 3. & Understatement & 21 & $20.9 \%$ \\
\hline 4. & Paradox & 07 & $6.9 \%$ \\
\hline 5. & Synecdoche & 06 & $5.9 \%$ \\
\hline 6. & Apostrophe & 02 & $1.9 \%$ \\
\hline 7. & Metonymy & 01 & $0.9 \%$ \\
\hline 8. & Total & 101 & $100 \%$ \\
\hline
\end{tabular}

Table 1. The Figurative Language Used in SPA's Headlines Pertaining Coronavirus 
Figurative Language Used in Saudi News Headlines Related to Coronavirus (Covid-19), Fadi Maher AlKhasawneh

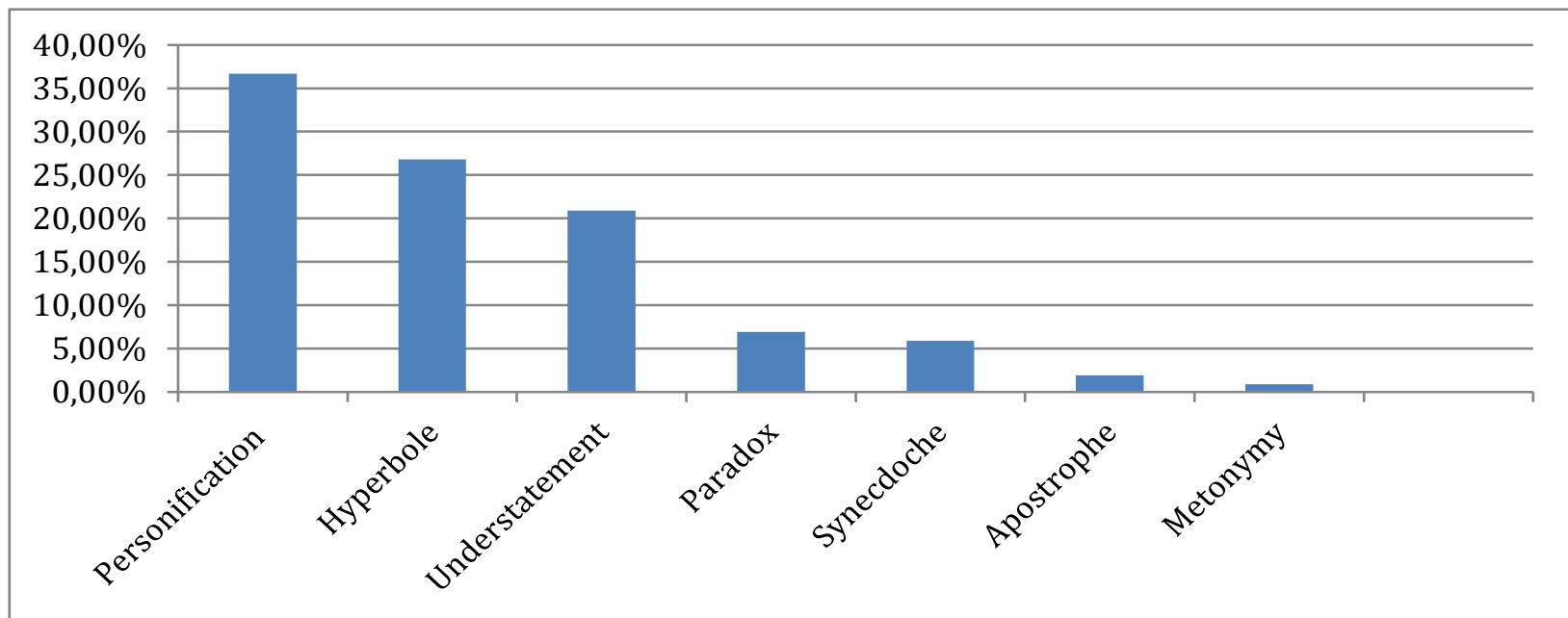

Figure 2: The Figurative Language Used in SPA's Headlines Pertaining Coronavirus

The findings of the study showed that there are seven types of speech figures used by SPA headlines pertaining to Coronavirus (COVID-19). These figures involve personification, hyperbole, understatement, paradox, synecdoche, apostrophe, and metonymy.

\subsubsection{Personification}

Personification involves giving one of the human characteristics to inanimate objects. In this study, personification has been used 37 times, and this contributes to (36.7\%) from the overall occurrences of speech figures. One example of personification is viewed in the following headline.

"COVID-19 cases in Jordan jump to 33"

Tuesday, March 17, 2020

This headline resembles a clear example of personification. The writer of this headline used the verb jump to indicate the increase of Coronavirus cases in Jordan. It is obvious that jumping is a human attribute, but it is used in this context to expand the meaning he wants to convey. Another example of personification is shown in the following example.

"Coronavirus victims exceeds 2.000 in Hubei province"

Tuesday, March $3^{\text {rd }}, 2020$

In this case of personification, the writer represents Coronavirus as a killer that has already killed 2.000 people. In fact, the bulk majority of the personification occurrences represented the virus as an enemy which should be combated. The main function of this resemblance is to raising readers' imagination through considering the battle we all face with the virus.

Another example of personification as appeared in one of the headlines related to Coronavirus is as follows:

"Coronavirus brought much fears of the people's daily life"

Thursday, April $2^{\text {nd }}, 2020$

In the above example, the writer resembles the virus as a man who could bring things. The writer pretends the virus to be a ghost who brings fears to other people. 


\subsubsection{Hyperbole}

Hyperbole involves using extravagant statements in headlines. The number of hyperbole cases mentioned in this study was 27 cases, and this contributes to $(26.8 \%)$ from the overall use of speech figures in headlines. The following headline shows an example of the used hyperbole.

"WHO Calls for Urgent and Aggressive Measures to Combat COVID-19 in South-East Asia" Tuesday, March 17, 2020

The writer uses the word aggressive to show serious and strict procedures and measures that need to be taken in order to face and avert the negative consequences of Coronavirus. The main function of this headline is to express a lot in a limited space. Actually, the word aggressive carries a lot of messages concerning the procedures of facing COVID-19.

\subsubsection{Understatement}

Understatement means to represent something less important than it really is. This study reported using this type of figurative language in 21 cases, which contributes to (20.9\%) from the overall occurrences of speech figures. The following statement shows an example of the understatement used in the selected headlines.

"G20 to Face Novel Coronavirus (COVID-19) Pandemic, with Swift, Decisive Action" Friday, March 13, 2020

This headline seeks to lessen the serious impact of Coronavirus spread around the world. The function of this headline was to create intense emotions for readers. It also tends to provide relaxation for readers through representing this virus as under control virus and could be avoided.

\subsubsection{Paradox}

A paradox is defined as a statement that seems contradictory but could have a meaningful idea. In the present study, this type of speech figure has been used 7 times which contributes to $(6.9 \%)$ of the overall use of figurative language. One interesting example of this type could be found in the following statement.

"The Jordanian Authority Claims: This is the Beginning of End of the Pandemic" Tuesday, March 31, 2020

The above-mentioned example seeks to create an intense emotion for the readers of this headline. People around the world are waiting for some solutions to cease the spread of the virus. This headline will, for sure, convey a sense of happiness and pleasure for readers.

\subsubsection{Synecdoche}

Synecdoche takes place when a part of something is used to show the whole thing. This type of speech figure has occurred 6 times and this contributes to (5.9\%) of the overall speech figures used in this study. The following statement is an example of this type of figurative language.

"Novel Coronavirus COVID-19 Follow-up Holds Its 9th Meeting"

Friday, February 28, 2020 
Figurative Language Used in Saudi News Headlines Related to Coronavirus (Covid-19), Fadi Maher AlKhasawneh

In this example, the follow-up of COVID-19 is actually referred to a special committee that is assigned to follow-up on the development of the virus spread. The use of word meeting is evidence that there is a committee concerning this issue, since the virus itself could not, definitely, holds a meeting.

\subsubsection{Apostrophe}

Apostrophe involves addressing absent, dead, or inanimate object. This type of speech figure occurred two times and that contributes to (1.9\%) of the total used speech figures. One of the instances of this type is shown in the following statement.

"WHO message to Youth on Coronavirus: You are not Invincible"

Friday, March 20, 2020

As seen in the above-mentioned example, the World Health Organization (WHO) addresses absent people who are actually the youth around the world. The pronoun you in this context refers to youth all over the world. The readers of this headline would definitely know that the addressee would not respond to the speaker in this context.

\subsubsection{Metonymy}

Metonymy has previously been mentioned as replacing the object of the sentence with another name which related in meaning. There was only one instance of metonymy and this contributes to $(0.9 \%)$ of the total used speech figures in this study. The following statement reveals the only case of metonymy in this study.

"Saudi Press: Staying at Home Is Our Strongest Weapon to Face Coronavirus"

Monday, March 23, 2020

In this case of metonymy, the writer represents staying at home as the strongest weapon to avert Coronavirus. The function of using this phrase was to emphasize the importance of adherence to domestic quarantine. The function of this headline was also to expand the imagination of readers, as they could imagine the battle we are having with this virus and to stay at home is the most effective weapon to avoid it.

The findings of this study revealed that the figurative language mostly used in news headlines related to Coronavirus was personification, hyperbole, and understatement. These results contradict the findings obtained from Al-Qudsy (20160 and Lammichhane's (2017) studies. In Al-Qudsy's (2016) study, the most used figurative speech was simile, synecdoche, and metaphor, while in Lamimichhane's (2017) study, the most frequently used speech figures were alliteration and metaphor. The different results between the present study and the previous studies could be attributed to the context under investigation. The context of Al-Qudsy's (2016) study was the use of speech figures in news headlines of two local issues, while the context of Lamimichhane's (2017) study was to investigate the use of the figurative language of selected news headlines in two Nepalese newspapers. The context of the present study is to investigate the use of figurative language in news headlines related to Coronavirus.

\section{Conclusion}

The main purpose of this study was to explore the types of figurative language used in online news related to the novel Coronavirus (COVID-19). The findings of this study showed that there were seven types of figurative language used in Saudi news headlines. These 
types were Personification, Hyperbole, Understatement, Paradox, Synecdoche, Apostrophe, and Metonymy. The most used speech figure used in this study was Personification with 37 instances, while the least used type was Metonymy with only one instance. The function of using those speech figures varies; one function was to expand meaning, increase readers' imagination, add emotional intensity, and to express a lot in a limited space. On the other hand, the use of figurative language could be perilous since not all readers can interpret the actual meaning that speech figures intend to convey. People who could appropriately interpret the actual meaning of speech figures, they could find the use of figurative language more interesting, attractive, and encourage them to read the whole news.

The present study explored the types and functions of figurative language used in Saudi news headlines related to Coronavirus (COVID-19). However, there are many other areas of speech figures that could be analyzed such as movies, comics, and novels. This study explored the use of figurative language following Perrine's (1969) theory of speech figures. Future research is advised to explore the use of speech figures following other theories such as Verdonks and Rozaki's theories. Finally, the researcher hopes that the findings of this study have contributed to the body of literature regarding this topic. In fact, the present study focused on figurative language use related to a novel pandemic, which we all hope from the almighty Allah to avoid this sorrow as soon as possible.

\section{Acknowledgments}

The author extends his appreciation to the Deanship of Scientific Research at King Khalid University for funding this work through the General Research Project under grant number (R.G.2/103/42).

\section{References}

Al-Qudsy, W. B. (2016). A Stylistic Analysis of figures of speech in the Jakarta Post Headlines under the issue of KPK VS. Polri. Sastra Inggris-Quill, 5(3), 202-208.

Chen, B. (2018). Metaphors in English news headlines. International Symposium on Humanities and Social Sciences, Management and Education Engineering, 266, 327330.

Chuang, C. L. (2012). Metaphor and metonymy in Apple Daily's headlines. In Proceedings of the 24th Conference on Computational Linguistics and Speech Processing (ROCLING 2012),176-184.

Furniss, G. (1996). Poetry, prose, and popular culture in Hausa. Washington: Smithsonian; Edinburgh: EUP; Ibadan: IUP.

Kennedy, X. J. \& Gioia, D. (2007). Literature: an introduction to fiction, poetry, drama, and writing (10th Ed). New York: Pearson Longman.

Kuolie, K. (2010). Stylistics and tenyimia invocation poetry. Journal of Literature, Culture and Media Studies, 2(3).

Lamichhane, M. (2017). The stylistic features of newspaper headlines. Doctoral dissertation, Faculty of Education Tribhuvan University, Kirtipur Kathmandu, Nepal.

Leech, G. N., \& Short, M. (2007). The style in fiction: a linguistic introduction to English fictional prose (No. 13). Pearson Education.

Moe, S. (2014). A brief study on the language of newspaper headlines used in "The New Light of Myanmar". Hinthada University Research Journal, 5(1), 82-92. 
Figurative Language Used in Saudi News Headlines Related to Coronavirus (Covid-19), Fadi Maher AlKhasawneh

Nurfiyanti, N. (2016). The figurative language used in one of the Jason Mraz albums in 2008 Entitled "We Sing, We Dance, We Steal Things. doctoral dissertation, Fakultas Tarbiyah dan Ilmu Keguruan).

Perrine, L. (1969). Sound and sense: an introduction to poetry (3rd Ed). New York: Harcourt, Brace \& World, Inc.

Saxena, S. (2006). Headline writing. New Delhi: Sage Publications India Pvt Ltd.

Shereen, M. A., Khan, S., Kazmi, A., Bashir, N., \& Siddique, R. (2020). COVID-19 infection: origin, transmission, and characteristics of human coronaviruses. Journal of Advanced Research, 24, 91-98.

Simpson, P. (2004). Stylistics: a resource book for students. London: Routledge.

Verdonk, P. (2002). Stylistics. Oxford: Oxford University Press.

Widdowson, H.G. (1975). Stylistics and the teaching of literature. London: Longman Publication.

Widyanti, N. (2013). A stylistic-pragmatic analysis of figurative language in Harper's Bazaar Magazine Advertisement. Undergraduate Thesis. Yogyakarta: Yogyakarta State University. 